\title{
Ideologies of Eastness in Central and Eastern Europe.
}

By TOMASZ ZARYCKI. (BASEES Routledge Series on Russian and East European Studies). Pp. 293. Oxon: Routledge. 2014. £90.00. Hardback. ISBN: 9780415625890.

Tomasz Zarycki's Ideologies of Eastness in Central and Eastern Europe is a compellingly argued contribution to the growing field of literature on discourses of Orientalism in Central and Eastern Europe. Despite the geographic breadth suggested in the title, Zarycki makes clear from the outset that the focus of the analysis will be Eastern Poland. The book is therefore essentially an exploration of the mechanisms behind the stigmatisation of Eastness; both in terms of inter-European relations, but also within internal Polish discourses. Zarycki explains such processes with reference to what he terms 'ideologies of Eastness' (p.1). He contends that there is a multitude of such ideologies in operation across economic, cultural, and political hierarchies, creating center-periphery dependencies at the international and domestic level.

Chapter 1 offers a broad introduction to Ideologies of Eastness, locating the narrative within the context of Edward Said's Orientalism (1978). Zarycki is careful to discern the uniqueness of the Central and Eastern European context from Said's Middle Eastern Orient, noting the borderland and, later, the non-threatening aspect of the region's identity. He fully elaborates upon his theoretical influences in Chapter 2, positioning Central and Eastern Europe as peripheral to, and semi-dependent upon, the Western Core. He notes the relevance of Stein Rokkan's analysis of power cleavages, Pierre Bourdieu's work on theories of capital and the field of power, as well as Immanuel Wallerstein's world system theory, to his understanding and analysis of the mechanisms underpinning this relationship. Within this chapter Zarycki also outlines his zone-based approach to the study of Central and Eastern Europe, the most relevant of which is zone one, encompassing Western influenced, but previously Soviet controlled, regions of Central Europe, e.g. Poland and Hungary.

Upon this platform, Zarycki uses Chapters 3 and 4 to develop two key ideologies of Eastness: firstly, the 'dependence doxa' (p.32) and, secondly, the 'intelligentsia doxa' (p.64). Zarycki defines the former as the 'naturalization of [Central and Eastern European] structural dependence on the West' (p.32), questioning the traditionally accepted knowledge that the supposed backwardness of the region is a Communist legacy, rather than a consequence of over dependence on the West, for example, through EU inflicted structural violence. For Zarycki, the intelligentsia doxa refers to the distinct role of cultural elites in zone one, in terms of the way in which this group can utilise cultural capital to legitimate political and economic hierarchies. Particularly referring to the liberal, pro-Europe elite, he notes the role of intelligentsia in communicating and reinforcing the dependent relationship between zone one and the Western core. Chapter five marks the conclusion of the theory-centric chapters of the analysis, questioning the application of post-colonial theory to 
Central and Eastern Europe, again noting the problematic nature of attributing the difficulties facing the region to historical, rather than contemporary, dependencies.

Within Chapters 6 and 7, Zarycki moves to concentrate specifically on the Polish case, exploring the ideologies of Eastness that have been constructed to engage with the Eastern sections of the country. He begins by considering the Kresy or 'old borderlands' discourse (p.115), noting that the Polish liberal intelligentsia have demarcated this narrative as exclusive and Orientalist. As he notes however, in castigating proponents of the Kresy discourse, this elite stratum in turn become the Orientaliser. For Zarycki, the liberal intelligentsia ascribe to a new borderlands discourse, in which Eastern Poland is presented as a diverse, forward-looking hub of cultural flourishing. He contends, however, that such discourses mask the power relations between the Polish centre and periphery; a reflection of the dependence doxa, which in turn conceals the dependency of zone one regions upon the Western core. The analysis reaches a crescendo in Chapter 8, in which Zarycki, following a historical discussion of Eastern Poland, persuasively applies his theoretical contentions to the development of the regions of Białystok, Lublin and, briefly, Rzeszów. Chapter 9 offers some supplementary reflections upon Ukrainian, Lithuanian, and Belarusian responses to Polish discourses on the East, whilst Chapter 10 offers concise, but considered, concluding notes.

The thoughtful and systematic organisation of the book, as well as the liberal use of examples, makes for a convincing read. There are, however, a few instances where further explanation would have been merited. A hurried reinterpretation of Mikhail Bakhtin's understanding of polyphony and dialogue certainly requires further consideration. Similarly, Zarycki's characteristic rejection of the debunking of 'stereotypes' and 'myths' (p.259) in favour of research that strives to understand the social construction of such ideas is called into question, when it appears he himself partakes in such activity in relation to the development of Polish territories under Russian imperial rule. These are minor quibbles however, and it is telling of the quality of Zarycki's analysis that the reader is left desiring further explanation, rather than frustrated at the lack thereof. Ideologies of Eastness should be of interest to those concerned with processes of othering and Orientalising within any regional context, but especially to those working in the field of Central and Eastern European studies.

\section{Ruth McKenna}

Department of Central and East European Studies

University of Glasgow

This work is licensed under the Creative Commons Attribution-Non-commercial-Share-alike 2.0 UK: England \& Wales License. This license allows for redistribution and alteration, commercial and noncommercial, as long as credit is given to the author. To view a full copy of this license, visit: http://creativecommons.org/licenses/ or send a letter to Creative Commons, 444 Castro Street, Suite 900, Mountain View.

(C) School of Slavonic and East European Studies, University College London, 2014. 